\title{
Methanol Assimilation by Hyphomicrobium sp.
}

\author{
By W. HARDER,* MARGARET M. ATTWOOD AND J. R. QUAYLE \\ Department of Microbiology, University of Sheffield, Sheffield. S Iо $2 T N$
}

(Received 7 March 1973)

\begin{abstract}
SUMMARY
A study has been made in methanol- and ethanol-grown Hyphomicrobium $\mathrm{x}$ of the specific activities of the following enzymes: serine hydroxymethyltransferase, serine-glyoxylate aminotransferase, hydroxypyruvate reductase, glycerate kinase, phosphopyruvate hydratase, phosphopyruvate carboxylase, serine dehydratase, malate dehydrogenase (decarboxylating), phosphopyruvate synthase, phosphopyruvate carboxykinase, glycerate phosphomutase, malate dehydrogenase, malate lyase (CoA acetylating-ATP cleaving), citrate synthase, aconitate hydratase, isocitrate lyase and malate synthase. It was concluded that during growth on ethanol the glyoxylate cycle operated, while during growth on methanol, $\mathbf{C}_{1}$ units and glyoxylate were converted to malate by the serine pathway. The glyoxylate was regenerated by cleavage of malate into glyoxylate and acetyl-CoA. The acetyl$\mathrm{CoA}$ was itself oxidized to glyoxylate by some of the reactions of the tricarboxylic acid cycle and isocitrate lyase, thus permitting net synthesis of $\mathrm{C}_{3}$ and $\mathrm{C}_{4}$ compounds from methanol and carbon dioxide.
\end{abstract}

\section{INTRODUCTION}

When an aerobic bacterium grows on reduced one-carbon compounds such as methanol either of two pathways, the serine pathway or the pentose phosphate cycle of formaldehyde fixation, is likely to be involved in the biosynthesis of cell constituents (Quayle, I972). The serine pathway has been most extensively investigated in Pseudomonas AMI and is thought to provide the route for synthesis of $\mathrm{C}_{3}$ and $\mathrm{C}_{4}$ intermediates during growth on $\mathrm{C}_{1}$ compounds by the following steps:

$$
\begin{aligned}
& \mathrm{C}_{1} \text { unit }+ \text { cofactors }+\mathrm{H}_{4} \text { folate } \rightarrow 5, \mathrm{IO}-\mathrm{CH}_{2}-\mathrm{H}_{4} \text { folate, } \\
& 5, \mathrm{IO}-\mathrm{CH}_{2}-\mathrm{H}_{4} \text { folate }+ \text { glycine } \rightleftharpoons \mathrm{H}_{4} \text { folate }+ \text { serine, } \\
& \text { Serine }+ \text { glyoxylate } \rightleftharpoons \text { hydroxypyruvate }+ \text { glycine, } \\
& \text { Hydroxypyruvate }+\mathrm{NADH}+\mathrm{H}^{+} \rightleftharpoons \text { glycerate }+\mathrm{NAD}^{+}, \\
& \text {Glycerate }+\mathrm{ATP} \rightarrow \text { phosphoglycerate }+ \text { ADP, } \\
& \text { Phosphoglycerate } \rightarrow \text { phosphoenolpyruvate, } \\
& \text { Phosphoenolpyruvate }+\mathrm{CO}_{2} \rightarrow \text { oxaloacetate }+\mathrm{Pi} \text {. }
\end{aligned}
$$

The essential features of this scheme are supported by the behaviour of several mutants lacking individual steps in the sequence (Heptinstall \& Quayle, 1970; Harder \& Quayle, I97I; Dunstan, Anthony \& Drabble, 1972). The serine pathway uses one molecule of glyoxylate (in reaction 3 ) to produce each molecule of phosphoglycerate or oxaloacetate. The mechanism of net synthesis of glyoxylate from $\mathrm{C}_{1}$ units remains unknown, although isotopic evidence from whole organisms indicated that it might arise from cleavage of $\mathrm{a} \mathrm{C}_{4}$ compound (Salem, Large \& Quayle, I972). Early isotopic studies with whole organisms of Hypho-

* Present address. Department of Microbiology, University of Groningen, Kerklaan 30, Haren (Gr.), Holland. 


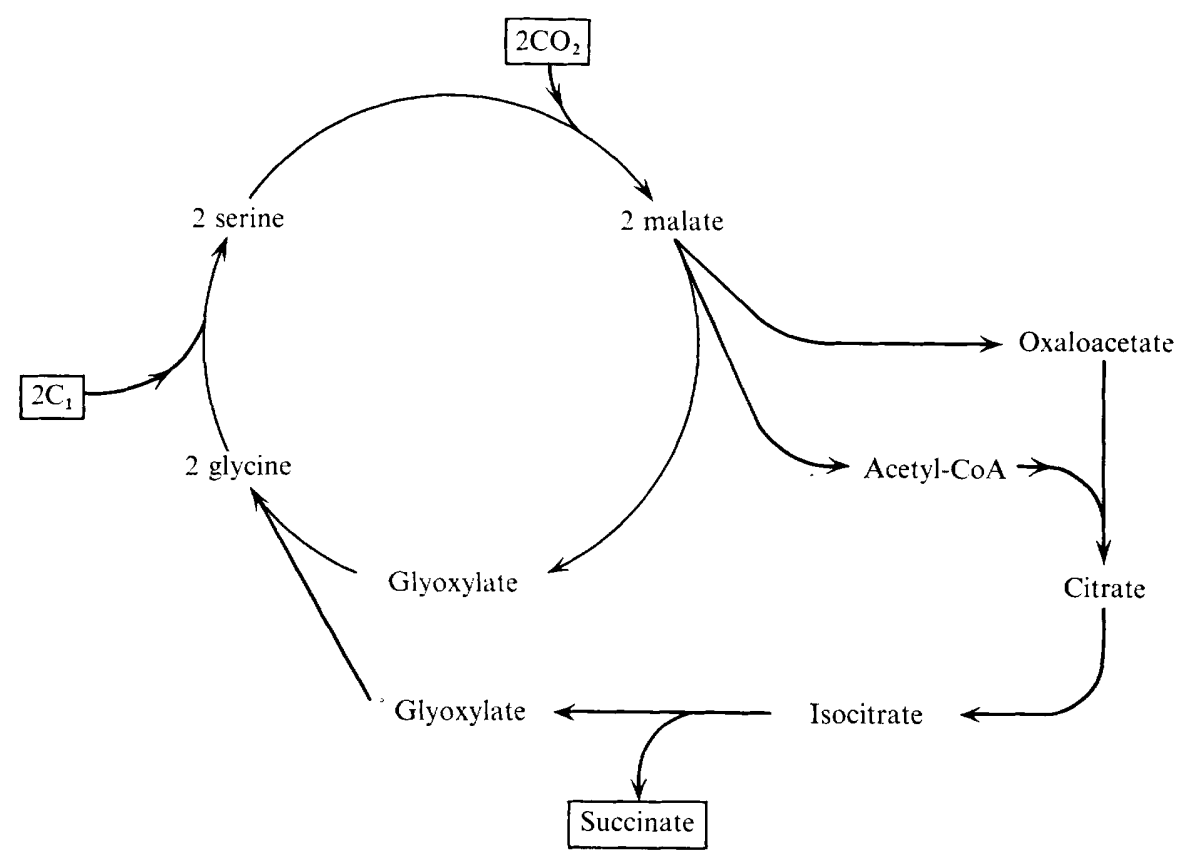

Scheme. 1. Pathway of $\mathrm{C}_{1}$ assimilation in methylamine-grown Pseudomonas MA (Bellion \& Hersh, 1972).

microbium vulgare indicated that the serine pathway was used for carbon assimilation during growth on methanol (Large, Peel \& Quayle, 196I) but no enzymatic studies with cell-free extracts were reported.

Enzymes of the serine pathway have recently been found in extracts of methylamine-grown Pseudomonas MA (Bellion \& Hersh, 1972). These authors showed the occurrence of reactions (2) and (4), transamination of glyoxylate with glutamate in a reaction similar to (3), and also serine dehydratase and malate dehydrogenase (decarboxylating) catalysing respectively:

$$
\begin{aligned}
& \text { Serine } \rightarrow \text { pyruvate }+\mathrm{NH}_{3}, \\
& \text { Pyruvate }+\mathrm{CO}_{2}+\mathrm{NAD}(\mathrm{P}) \mathrm{H}+\mathrm{H}^{+} \rightleftharpoons \text { malate }+\mathrm{NAD}(\mathrm{P})^{+} .
\end{aligned}
$$

The authors suggest that there operates in Pseudomonas MA either the serine pathway or a variant of it in which reactions (3) to (7) are replaced by reactions (8) and (9). The key observation was also made that the organism contained malate lyase (ATP cleaving-CoA acetylating) (Tuboi \& Kikuchi, I963) and isocitrate lyase, catalysing respectively:

$$
\begin{aligned}
& \text { Malate }+\mathrm{ATP}+\mathrm{CoA} \rightleftharpoons \text { glyoxylate }+ \text { acetyl-CoA }+\mathrm{ADP}+\mathrm{Pi}, \quad \text { (Io) } \\
& \text { Isocitrate } \rightleftharpoons \text { glyoxylate }+ \text { succinate. }
\end{aligned}
$$

These reactions were incorporated into a cyclic pathway (scheme I) for the net synthesis of succinate from two molecules of methylamine and two molecules of carbon dioxide (Bellion \& Hersh, 1972). It was noted that such a pathway might operate during growth of Hyphomicrobium WC on methylamine since this organism contained malate lyase (Hersh \& Bellion, 1972).

The isolation of strains of Hyphomicrobium which grow rapidly and without troublesome pellicle formation in mineral media with methanol as the sole source of carbon and energy (Attwood \& Harder, 1972) made it possible to study in detail the carbon assimilation by such organisms. The present paper describes the results of these studies. 


\section{Growth of the organism}

\section{METHODS}

Hyphomicrobium strains $\mathrm{X}$ and $\mathrm{G}$ were isolated as described by Attwood \& Harder (1972). Both strains were maintained on an inorganic salts medium containing methanol $(0.2 \%$, $\mathrm{v} / \mathrm{v}$ ) and agar $(\mathrm{r} \cdot 0 \% \mathrm{w} / \mathrm{v})$ (Attwood \& Harder, 1972). The organisms were transferred monthly; slopes were incubated at $30{ }^{\circ} \mathrm{C}$ for 5 to 7 days and then stored at $4{ }^{\circ} \mathrm{C}$. Growth in liquid medium was in 2-1 conical flasks containing $500 \mathrm{ml}$ of the salts medium supplemented with methanol or ethanol $(0.5 \%, \mathrm{v} / \mathrm{v})$. The flasks were inoculated with a $2 \%$ inoculum of organism, grown on the same carbon source, and incubated on a shaker at $30^{\circ} \mathrm{C}$. Organisms from the mid-exponential phase of growth were harvested by centrifugation at $6500 \mathrm{~g}$ for $20 \mathrm{~min}$. The organisms were washed twice with sodium-potassium phosphate buffer $(50 \mathrm{mM}$, $\mathrm{pH} 7.0)$ and then either resuspended in the same buffer containing 2-mercaptoethanol ( $2 \mathrm{~mm})$ or frozen at $-20^{\circ} \mathrm{C}$. Determinations of the specific growth rate, $\mu(\mu=(\mathrm{I}(d x / x), d t)$ where $x$ is a function of organism mass), were made by following the change in extinction at $430 \mathrm{~nm}$ using conical flasks $(250 \mathrm{ml})$ fitted with optically matched side arms.

\section{Preparation of cell-free extracts}

Bacteria were disrupted in an ultrasonic disintegrator (M.S.E. model 6oW) by treating a suspension of I $\mathrm{g}$ wet wt of organisms in $4 \mathrm{ml}$ of sodium-potassium phosphate buffer $(50 \mathrm{mM}$, $\mathrm{pH} 7{ }^{\circ}$ ) containing 2-mercaptoethanol $\left(2 \mathrm{~mm}\right.$ ) for $3 \times \mathrm{I}$ min at $0^{\circ} \mathrm{C}$ (power output $60 \mathrm{~W}$ at $25 \mathrm{kHz}$ ). Extracts were used after centrifugation at $\mathrm{I} 5000 \mathrm{~g}$ for $\mathrm{I} 5 \mathrm{~min}$.

\section{Protein determination}

Protein was assayed by the Folin-Ciocalteu method as described by Lowry, Rosebrough, Farr \& Randall (I95I). Bovine serum albumin was used as the standard.

\section{Chemicals}

Acetyl-CoA was prepared as described by Stadtman (1957). ( \pm )-Tetrahydrofolic acid was obtained from Sigma (London) Chemical Co. Ltd, London S.W.6. Purified enzymes, nicotinamide nucleotides, nucleotides and coenzyme A were obtained from Boehringer Corporation (London) Ltd, London W. 5.

\section{Enzyme assays}

All spectrophotometric assays were performed on a Unicam SP I 800 spectrophotometer at $30^{\circ} \mathrm{C}$. The amounts of enzymes to be assayed were such that rates were linear with respect to time for at least $3 \mathrm{~min}$ and were proportional to the amount of extract added.

Serine hydroxymethyl transferase (EC 2.I.2.1). The enzyme was assayed by a method based on that of Heptinstall \& Quayle (I970). The reaction mixture contained $40 \mu \mathrm{mol}$ of maleic acid-potassium hydroxide buffer, $\mathrm{pH} 6.9$; I $\mu \mathrm{mol}$ of NADP, $0.2 \mu \mathrm{mol}$ of pyridoxal phosphate, $20 \mu \mathrm{mol}$ of 2 -mercaptoethanol, $0.5 \mu \mathrm{mol}$ of $( \pm)$ tetrahydrofolate, $20 \mu \mathrm{mol}$ of $\mathrm{L}$-serine and extract in a total volume of $\mathrm{I} \cdot 0 \mathrm{ml}$. Serine was added to start the reaction. The assay is dependent on the activity of methylene tetrahydrofolate dehydrogenase which was present in excess over serine hydroxymethyl transferase in the Hyphomicrobium extracts. Addition of purified methylene tetrahydrofolate dehydrogenase from Pseudomonas AM I did not change the rate of NADP reduction in the above assay system.

Serine dehydratase (EC 4.2. I . I3) was assayed by measuring with lactate dehydrogenase the pyruvate produced from serine by dehydration. Reaction mixtures contained $100 \mu \mathrm{mol}$ tris- $\mathrm{HCl}$ buffer, $\mathrm{pH} 7.5$, Io $\mu \mathrm{mol} 2$-mercaptoethanol, $0.02 \mu \mathrm{mol}$ pyridoxal phosphate, 
$0.15 \mu \mathrm{mol} \mathrm{NADH}, 2.5 \mu \mathrm{g}$ lactate dehydrogenase and extract in a final volume of $\mathrm{I} \cdot 0 \mathrm{ml}$. The reaction was allowed to proceed for several minutes in the absence of serine to determine the activity of NADH oxidase. L-Serine $(50 \mu \mathrm{mol})$ was then added and the difference in the rate of NADH oxidation in the presence and absence of serine was used to determine enzyme activity.

Malate lyase (CoA acetylating-ATP cleaving) was assayed by measuring the cleavage of malate to glyoxylate in the presence of phenylhydrazine in a modification of the method described by Bellion \& Hersh (1972). Reaction mixtures contained $40 \mu \mathrm{mol}$ potassium phosphate buffer, $\mathrm{pH} 7 \cdot 0,20 \mu \mathrm{mol}$ ATP, $0.5 \mu \mathrm{mol}$ coenzyme A, $10 \mu \mathrm{mol} \mathrm{MgCl}_{2}, 20 \mu \mathrm{mol}$ 2-mercaptoethanol, 3.5 $\mu \mathrm{mol}$ phenylhydrazine (recrystallized) and extract to a final volume of $\mathrm{I} .0 \mathrm{ml}$. The reaction was started by the addition of $20 \mu \mathrm{mol} \mathrm{L}$-malate and the formation of glyoxylate phenylhydrazone was measured at $324 \mathrm{~nm}\left(E_{324}=\mathrm{I} \cdot 7 \times 10^{4}\right)$. Enzyme activity was strictly dependent upon the presence of CoA and ATP.

Malate dehydrogenase (EC I . I . I . 37) was assayed by following the oxaloacetate-dependent oxidation of NADH or NADPH at $340 \mathrm{~nm}$. Reaction mixtures contained $50 \mu \mathrm{mol}$ tris- $\mathrm{HCl}$ buffer, $\mathrm{pH} 8 \cdot 0, \mathrm{I} \mu \mathrm{mol} \mathrm{MnSO}_{4}, 0.15 \mu \mathrm{mol}$ either NADH or NADPH, I0 $\mu \mathrm{mol}$ oxaloacetate and extract to a final volume of $\mathrm{I} \cdot 0 \mathrm{ml}$.

Glycerate kinase (EC 2.7.I.3I) was assayed by the method described by Heptinstall \& Quayle (1970), except that $50 \mu \mathrm{mol}$ tris- $\mathrm{HCl}$ buffer, $\mathrm{pH} 7 \cdot 5$, was used instead of phosphate buffer.

Glycerate phosphomutase (EC 2.7.5.3) was assayed by a modification of the method described in the Biochemica catalogue (1968), C. F. Boehringer \& Soehne GmbH, Mannheim, Germany. The reaction mixture contained $50 \mu \mathrm{mol}$ tris- $\mathrm{HCl}$ buffer, $\mathrm{pH} 7 \cdot 5,10 \mu \mathrm{mol}$ $\mathrm{MgCl}_{2}, 5 \mu \mathrm{mol}$ 3-phosphoglycerate, 0.I5 $\mu \mathrm{mol} \mathrm{NADH}, 0.5 \mu \mathrm{mol}$ ADP, $0.1 \mu \mathrm{mol} \mathrm{2,3-}$ diphosphoglycerate, $25 \mu \mathrm{g}$ lactate dehydrogenase, Io $\mu \mathrm{g}$ pyruvate kinase, $50 \mu \mathrm{g}$ phosphopyruvate hydratase and bacterial extract in a total volume of $\mathrm{I} \mathrm{ml}$. The reaction was followed by measuring the decrease in absorbance at $340 \mathrm{~nm}$. The activity of this enzyme in Hyphomicrobium extracts was higher when ATP was added to the reaction mixture (Table 3), so $0.6 \mu \mathrm{mol}$ ATP was added to reaction mixtures unless stated otherwise.

Phosphopyruvate hydratase (EC 4.2. I I I). This enzyme was assayed in a similar reaction mixture to that described for glycerate phosphomutase except that $5.6 \mu \mathrm{mol} 2$-phosphoglycerate was substituted for 3-phosphoglycerate while 2,3-diphosphoglycerate, ATP and phosphopyruvate hydratase were omitted.

Conversion of glycerate to phosphoenolpyruvate. This conversion was followed in a similar reaction mixture to that described above for glycerate phosphomutase except that I $\mu$ mol DL-glycerate was substituted for 3-phosphoglycerate and phosphopyruvate hydratase was omitted.

The following enzymes were assayed by published methods: hydroxypyruvate reductase, EC I.I. I .29 (Blackmore \& Quayle, 1970); phosphoenolpyruvate (PEP) carboxylase, EC 4.I.I.3I (Cánovas \& Kornberg, I969); pyruvate carboxylase, EC 6.4.I. I (Seubert \& Weicker, 1969); PEP carboxykinase, EC 4. I I .32 (Wright \& Sanwal, I969); PEP synthase (Cooper \& Kornberg, I969); malate dehydrogenase (decarboxylating) EC I. I . I.39 and EC I . I . I .40 (Hsu \& Lardy, I 969); isocitrate lyase, EC 4. I . 3 . I (Dixon \& Kornberg, I959); citrate synthase, EC 4.1.3.7 (Srere, 1969); malate synthase, EC 4.1.3.2 (Dixon \& Kornberg, 1969); aconitate hydratase, EC 4.2.13 (Fansler \& Lowenstein, 1969); isocitrate dehydrogenase, EC I . I. I .4I and EC I I . I . 42 (Cleland, Thompson \& Barden, I969). 
Table I. Specific activities of enzymes involved in metabolism of $C_{3}$ compounds in extracts of methanol-and ethanol-grown Hyphomicrobium $\mathrm{x}$

Assay methods are described in the Methods section. The duplicate values are taken from measurements made on batches of organisms grown separately.

\section{Enzyme}

Serine hydroxymethyl transferase Serine glyoxylate aminotransferase Hydroxypyruvate reductase Glycerate kinase

Phosphopyruvate hydratase Phosphoenolpyruvate carboxylase Serine dehydratase Malate dehydrogenase (decarboxylating) (NAD) Malate dehydrogenase (decarboxylating) (NADP) Phosphoenolpyruvate synthase Phosphoenolpyruvate carboxykinase Glycerate phosphomutase

\begin{tabular}{|c|c|}
\hline \multicolumn{2}{|c|}{ Specific activity $(\mu \mathrm{mol} / \mathrm{min} / \mathrm{mg}$ protein) } \\
\hline Methanol grown & Ethanol grown \\
\hline $0.4 \mathrm{I}$ & $0.099 \quad 0.095$ \\
\hline 0.14 & Not detected \\
\hline 0.65 & $0.065 \quad 0.057$ \\
\hline 0.037 & $0.003 \quad 0.003$ \\
\hline 0.20 & $0.35 \quad 0.33$ \\
\hline 0.18 & Not detected \\
\hline $0.007 \quad 0.007$ & $0.015 \quad 0.017$ \\
\hline Not detected & Not detected \\
\hline Not detected & $0.035 \quad 0.048$ \\
\hline Not detected & Not detected \\
\hline$<0.0002$ & $0.002 \quad 0.0025$ \\
\hline $\begin{array}{ll}0.035 & 0.037\end{array}$ & 0.057 \\
\hline
\end{tabular}

\section{RESULTS AND DISCUSSION}

The experiments described in this section have been performed with two strains of Hyphomicrobium, strains $\mathrm{X}$ and $\mathrm{G}$. The results obtained were essentially similar and in the following tables only the data for strain $\mathrm{x}$ are presented. The growth rate of this strain at $30{ }^{\circ} \mathrm{C}$ in a mineral medium with methanol $(0.5 \%, \mathrm{v} / \mathrm{v})$ as the sole source of carbon and energy was $\mu_{\max }=0.10 \mathrm{~h}^{-1}$ (doubling time of $6.9 \mathrm{~h}$ ); with ethanol $(0.5 \%, \mathrm{v} / \mathrm{v}$ ) as the carbon and energy source the growth rate was $\mu=0.07 \mathrm{~h}^{-1}$ (doubling time of $9.8 \mathrm{~h}$ ). The organism was unable to grow on any of the several $\mathrm{C}_{3}, \mathrm{C}_{4}$ and $\mathrm{C}_{6}$ compounds tested as growth substrates (Attwood \& Harder, 1973).

\section{The enzymes of the serine pathway}

Enzymes catalysing each of the steps of the serine pathway (2) to (7) were found in extracts of Hyphomicrobium $\times$ (Table 1 ). That these enzymes play a major role in the assimilation of methanol is indicated by their higher specific activities (with two exceptions) in the organism grown on methanol as compared to ethanol. The exceptions are phosphopyruvate hydratase and glycerate phosphomutase which might, however, be expected to be involved in the metabolism of both these substrates. The lack of malate dehydrogenase (decarboxylating) and the low activity of serine dehydratase in methanol-grown organisms argues against the operation of the variant of the serine pathway in which reactions (3) to (7) are replaced by reactions (8) and (9).

\section{Regeneration of glyoxylate}

Enzymes necessary for the regeneration of glyoxylate and net synthesis of succinate from $\mathrm{C}_{1}$ compounds according to scheme I were present in extracts of methanol-grown Hyphomicrobium $\mathrm{x}$ (Table 2). The key role of malate lyase in growth on methanol is demonstrated by its presence in the methanol-grown organism and absence from the ethanol-grown organism. Operation of a sequence of reactions similar in outline to that in scheme I would be consistent with the isotopic studies of Large et al. (I96I) carried out on methanol-grown $H$. vulgare. These authors showed that with $\left[{ }^{14} \mathrm{C}\right]$ methanol incorporation, radioactive serine and glycollate contained most of the initially incorporated tracer; with ${ }^{14} \mathrm{CO}_{2}$ incorporation, 
Table 2. Specific activity of enzymes involved in the regeneration of glyoxylate in extracts of methanol-and ethanol-grown Hyphomicrobium $\mathrm{x}$

Assay methods are described in the Methods section. The duplicate values are taken from measurements made on batches of organisms grown separately.

\begin{tabular}{|c|c|c|}
\hline \multirow{3}{*}{$\begin{array}{c}\text { Enzyme } \\
\text { Malate dehydrogenase (NAD) }\end{array}$} & \multicolumn{2}{|c|}{ Specific activity $(\mu \mathrm{mol} / \mathrm{min} / \mathrm{mg}$ protein $)$} \\
\hline & Methanol grown & Ethanol grown \\
\hline & $1 \cdot 7$ & $8 \cdot 8 \quad 9 \cdot 9$ \\
\hline Malate lyase & 0.020 & Not detected \\
\hline Citrate synthase & 0.27 & $0.59 \quad 0.67$ \\
\hline Aconitate hydratase & 0.20 & 0.64 \\
\hline Isocitrate lyase & $0.020 \quad 0.023$ & 0.038 \\
\hline Malate synthase & Not detected & 0.045 \\
\hline
\end{tabular}

malate, aspartate and to a lesser extent, glycine, contained most of the initially incorporated tracer. It is assumed that glycollate may reflect the presence of glyoxylate through reduction with hydroxypyruvate reductase (Heptinstall \& Quayle, 1970); glyoxylate itself would not have been detected under the conditions of chromatography that were employed.

The presence of malate synthase and isocitrate lyase in the ethanol-grown organism is consistent with the operation of the glyoxylate cycle as the assimilatory pathway during growth on this substrate. It is interesting to note that the synthesis of malate synthase and isocitrate lyase does not appear to be co-ordinate in Hyphomicrobium $\mathrm{X}$ or Pseudomonas MA (Bellion \& Hersh, 1972), in contrast to Escherichia coli where their synthesis may be controlled as an operon (see Kornberg, 1970).

\section{Formation of phosphoenolpyruvate from succinate}

It is generally thought that the formation of PEP necessary for gluconeogenesis occurs from $\mathrm{C}_{4}$ dicarboxylic acids via PEP carboxykinase (Scrutton \& Utter, 1969; Sanwal, I970):

$$
\text { Oxaloacetate }+\mathrm{NuTP} \rightleftharpoons \mathrm{PEP}+\mathrm{NuDP}+\mathrm{CO}_{2} \text {. }
$$

This role for PEP carboxykinase might be expected in an organism growing on a $\mathrm{C}_{2}$ substrate by way of the glyoxylate cycle, where succinate is the net assimilatory product; this could be the case for Hyphomicrobium $\mathrm{x}$ when grown on ethanol (Table $\mathrm{I}$ ). Since succinate might also be regarded as the net assimilatory product of an organism growing on $\mathrm{C}_{1}$ compounds by the sequence shown in scheme $\mathrm{I}$, the fact that the specific activity of PEP carboxykinase is one-tenth that during growth on ethanol (Table $\mathrm{I}$ ) suggests that a different mechanism of PEP synthesis may operate. Such a route is unlikely to proceed through the combined action of malate dehydrogenase (decarboxylating) and PEP synthase:

$$
\begin{aligned}
& \text { Malate }+\mathrm{NAD}(\mathrm{P})^{+} \rightleftharpoons \text { pyruvate }+\mathrm{CO}_{2}+\mathrm{NAD}(\mathrm{P}) \mathrm{H}+\mathrm{H}^{+}, \\
& \text {Pyruvate }+\mathrm{ATP} \rightleftharpoons \mathrm{PEP}+\mathrm{AMP}+\mathrm{Pi},
\end{aligned}
$$

since neither enzyme could be detected in extracts of methanol-grown Hyphomicrobium $\mathrm{x}$ (Table I). An alternative route of PEP synthesis, not involving PEP carboxykinase, may be devised by modifying scheme I into the sequence of reactions shown in scheme 2 . In the latter scheme, the succinate, instead of being withdrawn as the net output of the overall cycle, is used to regenerate the carbon skeleton of oxaloacetate which acts as acceptor for acetyl-CoA during its oxidation to glyoxylate. This then permits withdrawal of a $\mathrm{C}_{3}$ intermediate such as phosphoglycerate as the net output of an overall cycle whose input is two molecules of methanol and one molecule of carbon dioxide. 


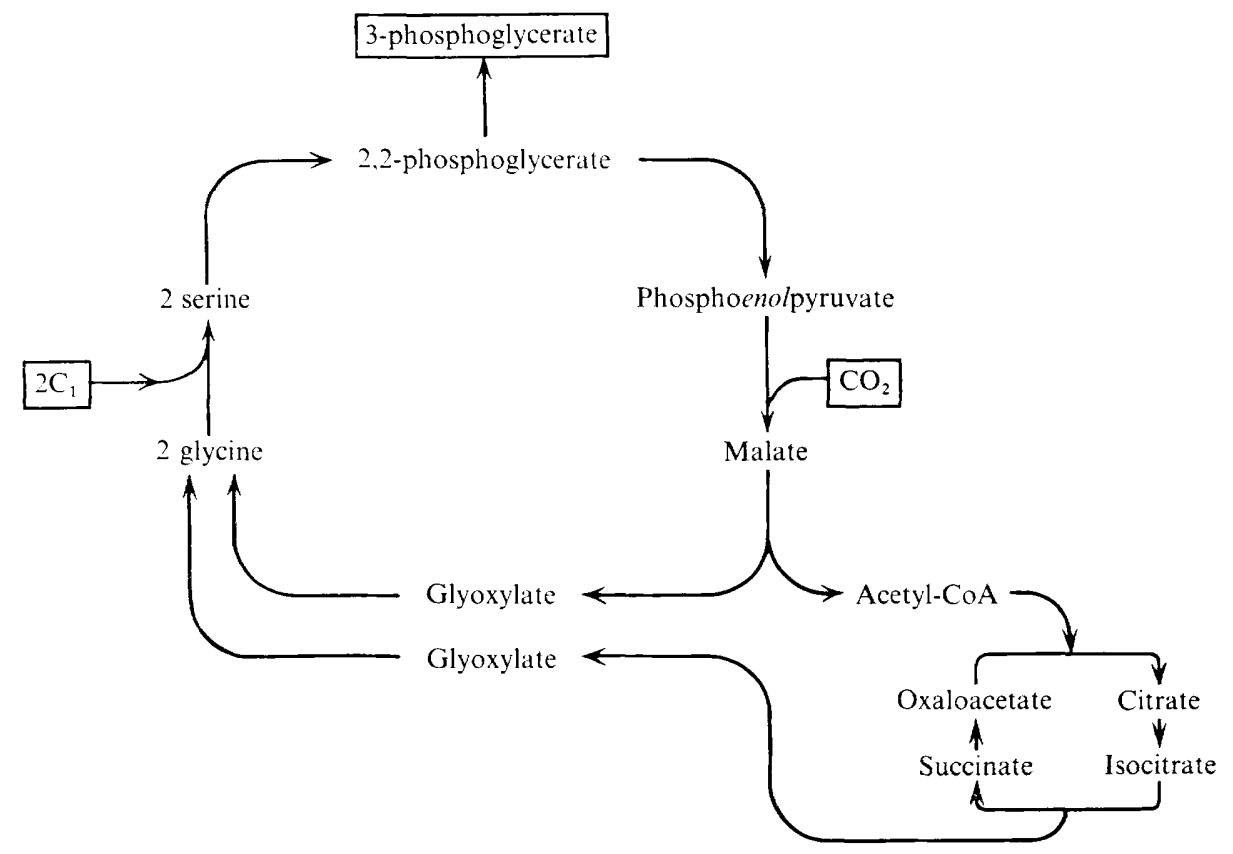

Scheme 2. Pathway of $\mathrm{C}_{1}$ assimilation in methanol-grown Hyphomicrobium $\mathrm{x}$.

\section{Conversion of glycerate into phosphoenolpyruvate}

Extracts of methanol-grown Hyphomicrobium $\mathrm{x}$ catalysed an ATP-dependent conversion of glycerate into PEP, via phosphoglycerate:

$$
\text { Glycerate + ATP } \rightarrow \text { PEP + ADP. }
$$

The rate of this conversion, measured spectrophotometrically by converting the PEP into lactate in the presence of excess pyruvate kinase, lactate dehydrogenase and NADH (see Methods), was 0.12 to $0.13 \mu \mathrm{mol} / \mathrm{min} / \mathrm{mg}$ protein in methanol-grown organisms and 0.067 to $0.083 \mu \mathrm{mol} / \mathrm{min} / \mathrm{mg}$ protein in ethanol-grown organisms. Under identical experimental conditions, the same extracts of methanol-grown organisms catalysed the conversion of 2phosphoglycerate to PEP with a specific activity of 0.200 to $0.203 \mu \mathrm{mol} / \mathrm{min} / \mathrm{mg}$ protein and the conversion of 3-phosphoglycerate to 2-phosphoglycerate with a specific activity of 0.035 to $0.037 \mu \mathrm{mol} / \mathrm{min} / \mathrm{mg}$ protein (Table I). These results show that reaction (I5) must proceed via, not 3-phosphoglycerate but only 2-phosphoglycerate as intermediate; the product of the glycerate kinase reaction is thus 2-phosphoglycerate as with the rat liver enzyme (Lamprecht, Heinz \& Diamartstein, 1962). Comparison of the specific activities of the enzymes shows that the 17 -fold higher rate of reaction (I5) in methanol-grown than in ethanol-grown organisms must be due to the higher specific activity of glycerate kinase, thus emphasizing its specific involvement in growth on methanol.

During the course of this work it was noted that $0.6 \mathrm{mM}$-ATP caused a $2 \cdot 5$-fold stimulation in the activity of glycerate phosphomutase; this was antagonized by AMP (Table 3). No such inhibitory effect was exerted on phosphopyruvate hydratase by 5 mM-AMP. Despite the inhibitory effect of AMP on glycerate phosphomutase, 5 mM-AMP did not affect the rate of conversion of glycerate to PEP; this further supports the view that this conversion does not proceed by way of 3-phosphoglycerate as an intermediate. It may be speculated 
Table 3. The effect of ATP and AMP on the activity of glycerate phosphomutase in extracts of methanol-grown Hyphomicrobium $\mathrm{X}$

$\begin{aligned} & \text { Assay methods are described in the Methods section. } \\ & \text { Amounts of ATP and AMP in } \\ & \text { the reaction mixture }\end{aligned}$
$\begin{array}{lc}\text { Sone } & 0.015 \\ 0.6 \mu \mathrm{mol} \text { ATP } & 0.037 \\ 0.6 \mu \mathrm{mol} \text { ATP }+0.6 \mu \mathrm{mol} \text { AMP } & 0.023 \\ 0.6 \mu \mathrm{mol} \text { ATP }+7.8 \mu \mathrm{mol} \text { AMP } & 0.008 \\ 6.6 \mu \mathrm{mol} \text { ATP }+7.8 \mu \mathrm{mol} \text { AMP } & 0.023\end{array}$

that the effects of ATP and AMP on glycerate phosphomutase might play a regulatory role by increasing the flow of carbon from the assimilation cycle, shown in scheme 2 , into synthesis of carbohydrate when the energy status of the cell is high, and vice versa (Atkinson, 1971).

We thank Mr D. J. Trott and Mr A. A. Hancock for technical assistance.

\section{REFERENCES}

Atkinson, D. E. (197I). In Metabolic Pathways, vol. v, p. I. Edited by Henry J. Vogel. New York and London: Academic Press.

AtTwOod, M. M. \& HARDER, W. (1972). A rapid and specific enrichment procedure for Hyphomicrobium spp. Antonie van Leeuwenhoek 38, 369-378.

ATTWOOD, M. M. \& HARDER, W. (1973). The metabolism of organic carbon compounds in Hyphomicrobia: metabolism of $\mathrm{C}_{2}$-compounds. Antonie van Leeuwenhoek (in the Press).

Bellion, E. \& Hersh, L. B. (1972). Methylamine metabolism in a Pseudomonas species. Archives of Biochemistry and Biophysics 153, 368-374.

BLACKMORE, M. A. \& QUAYLE, J. R. (I970). Microbial growth on oxalate by a route not involving glyoxylate carboligase. Biochemical Journal Ir8, 53-59.

CÁnovas, J. L. \& Kornberg, H. L. (1969). Phosphoenolpyruvate carboxylase from Escherichia coli. In Methods in Enzymology, vol. 13, pp. 288-309. Edited by J. M. Lowenstein. New York and London: Academic Press.

Cleland, W. W., Thompson, V. W. \& Barden, R. E. (I969). Isocitrate dehydrogenase (TPN-specific) from pig heart. In Methods in Enzymology, vol. 13, pp. 30-33. Edited by J. M. Lowenstein. New York and London: Academic Press.

COoper, R. A. \& KornBerg, H. L. (I969). Phosphoenolpyruvate synthase. In Methods in Enzymology, vol. I3, pp. 309-3 14. Edited by J. M. Lowenstein. New York and London: Academic Press.

Dixon, G. H. \& KornberG, H. L. (1959). Assay methods for key enzymes of the glyoxylate cycle. Biochemical Journal 72, 3 P.

Dixon, G. H. \& KornBerg, H. L. (I969). Malate synthase from baker's yeast. In Methods in Enzymology, vol. 5, pp. 633-637. Edited by S. P. Colowick and N. O. Kaplan. New York and London: Academic Press.

Dunstan, P. M., ANThony, C. \& Drabble, W. T. (1972). Microbial metabolism of $\mathrm{C}_{1}$ and $\mathrm{C}_{2}$ compounds. The role of glyoxylate, glycollate and acetate in the growth of Pseudomonas AMI on ethanol and on $\mathrm{C}_{1}$ compounds. Biochemical Journal 128, 107-115.

FANSLER, B. \& Lowenstein, J. M. (1969). Aconitase-from pig heart. In Methods in Enzymology, vol. 13, pp. 26-30. Edited by J. M. Lowenstein. New York and London: Academic Press.

HARDER, W. \& QUAYLE, J. R. (I97I). Aspects of glycine and serine biosynthesis during growth of Pseudomonas AMI on $C_{1}$ compounds. Biochemical Journal 12r, 763-769.

HePtinstall, J. \& QUayle, J. R. (1970). Pathways leading to and from serine during growth of Pseudomonas AMI on $C_{1}$ compounds or succinate. Biochemical Journal $117,563-572$.

Hersh, L. B. \& Bellion, E. (1972). Malate cleavage reaction in Pseudomonas species. Biochemical and Biophysical Research Communications 48, 7 I 2-719.

Hsu, R. Y. \& LARDY, H. A. (1969). Malic enzyme. In Methods in Enzymology, vol. I3, pp. 230-235. Edited by J. M. Lowenstein. New York and London: Academic Press. 
Kornberg, H. L. (1970). Mechanisms of carbohydrate synthesis from $C_{2}$ - and $\mathrm{C}_{3}$-acids. In Miami Winter Symposium, vol. I, pp. 103-I 21. Amsterdam: North-Holland Publishing Co.

Lamprecht, W., Heinz, F. \& Diamartstein, T. (I962). Phosphorylierung von D-Glycerinsäure zu 2-PhosphoD-Glycerinsäure mit Glyceratkinase in Leber. Identifizierung des Reaktionsproduktes durch Papierchromatographie. Zeitschrift für Physiologische Chemie 328, 204-206.

Large, P. J., Peel, D. \& Quayle, J. R. (I961). Microbial growth on $\mathrm{C}_{1}$ compounds. 2. Synthesis of cell constituents by methanol- and formate-grown Pseudomonas AMI, and methanol-grown Hyphomicrobium vulgare. Biochemical Journal 8r, 470-480.

Lowry, O. H., Rosebrough, N. J., Farr, A. L. \& Randall, R. J. (I95I). Protein measurement with the Folin phenol reagent. Journal of Biological Chemistry $\mathbf{1 9 3}, 265-275$.

QuAYLE, J. R. (1972). The metabolism of one-carbon compounds in micro-organisms. In Advances in Microbial Physiology, vol. 7, pp. I 19-203. Edited by A. H. Rose and D. W. Tempest. London and New York: Academic Press.

Salem, A. R., LARge, P. J. \& QUaYle, J. R. (1972). Glycine formation during growth of Pseudomonas AM I on methanol and succinate. Biochemical Journal 124, I203-1 211.

Sanwal, B. D. (1970). Allosteric controls of amphibolic pathways in bacteria. Bacteriological Reviews 30, 20-39.

Scrutton, M. C. \& Utter, M. F. (1969). The regulation of glycolysis and gluconeogenesis in animal tissues. Annual Review of Biochemistry 37, 249-302.

Seubert, W. \& Weicker, H. (1969). Pyruvate carboxylase from Pseudomonas. In Methods in Enzymology, vol. I3, pp. 258-262. Edited by J. M. Lowenstein. New York and London: Academic Press.

Srere, P. A. (1969). Citrate synthase. In Methods in Enzymology, vol. 13, pp. 3-1 I. Edited by J. M. Lowenstein. New York and London: Academic Press.

Stadtman, E. R. (I957). Preparation and assay of acyl coenzyme A and other thiol esters; use of hydroxylamine. In Methods in Enzymology, vol. 3, pp. 931-94I. Edited by S. P. Colowick and N. O. Kaplan. New York: Academic Press.

TuвoI, S. \& Kiкuchi, G. (I963). Enzymic cleavage of malate to glyoxylate and acetyl-coenzyme A. Journal of Biochemistry, Japan 53, 364-373.

Wright, J. A. \& SANwAL, B. D. (I969). Regulatory mechanisms involving nicotinamide adenine nucleotides as allosteric effectors. II. Control of phosphoenolpyruvate carboxykinase. Journal of Biological Chemistry 244, I 838-I 845. 